\title{
Front Matter: Volume 6837
}

, "Front Matter: Volume 6837," Proc. SPIE 6837, Information Optics and

Photonics Technologies II, 683701 (25 January 2008); doi: 10.1117/12.785148

SPIE. Event: Photonics Asia 2007, 2007, Beijing, China 


\title{
PROCEEDINGS OF SPIE
}

\section{Information Optics and Photonics Technologies II}

\author{
Guoguang Mu \\ Feijun Song \\ Francis T. S. Yu \\ Suganda Jutamulia \\ Editors
}

\section{2-13 November 2007 \\ Beijing, China}

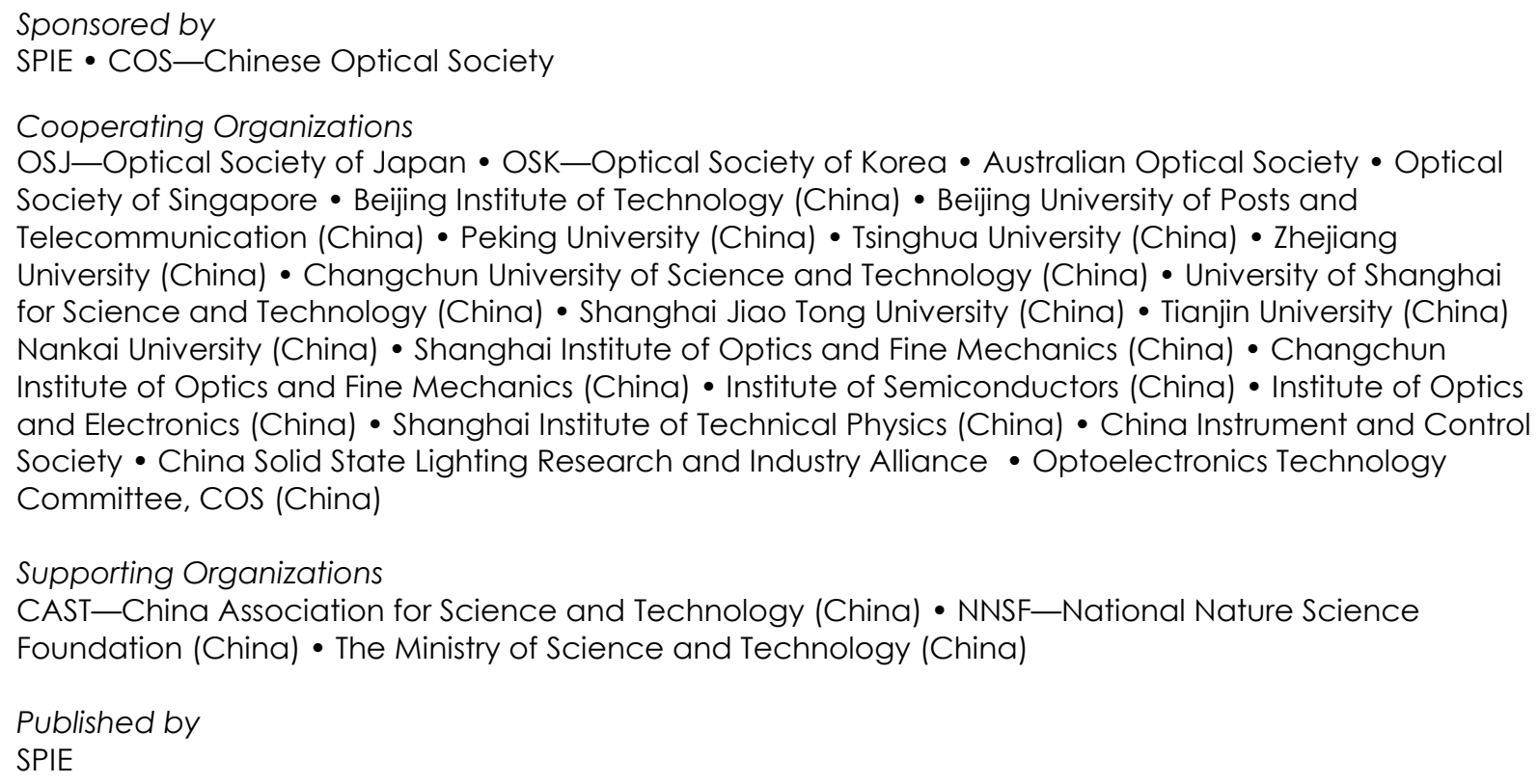

Volume 6837 
The papers included in this volume were part of the technical conference cited on the cover and title page. Papers were selected and subject to review by the editors and conference program committee. Some conference presentations may not be available for publication. The papers published in these proceedings reflect the work and thoughts of the authors and are published herein as submitted. The publisher is not responsible for the validity of the information or for any outcomes resulting from reliance thereon.

Please use the following format to cite material from this book:

Author(s), "Title of Paper," in Information Optics and Photonics Technologies II, edited by Guoguang Mu, Feijun Song, Francis T. S. YU, Suganda Jutamulia, Proceedings of SPIE Vol. 6837 (SPIE, Bellingham, WA, 2007) Article CID Number.

ISSN 0277-786X

ISBN 9780819470126

Published by

SPIE

P.O. Box 10, Bellingham, Washington 98227-0010 USA

Telephone +1 3606763290 (Pacific Time) · Fax +1 3606471445

SPIE.org

Copyright (c) 2008, Society of Photo-Optical Instrumentation Engineers

Copying of material in this book for internal or personal use, or for the internal or personal use of specific clients, beyond the fair use provisions granted by the U.S. Copyright Law is authorized by SPIE subject to payment of copying fees. The Transactional Reporting Service base fee for this volume is $\$ 18.00$ per article (or portion thereof), which should be paid directly to the Copyright Clearance Center (CCC), 222 Rosewood Drive, Danvers, MA 01923. Payment may also be made electronically through CCC Online at copyright.com. Other copying for republication, resale, advertising or promotion, or any form of systematic or multiple reproduction of any material in this book is prohibited except with permission in writing from the publisher. The CCC fee code is 0277-786X/08/\$18.00.

Printed in the United States of America.

Publication of record for individual papers is online in the SPIE Digital Library.

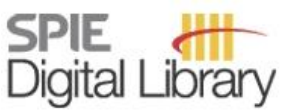

SPIEDigitalLibrary.org

Paper Numbering: Proceedings of SPIE follow an e-First publication model, with papers published first online and then in print and on CD-ROM. Papers are published as they are submitted and meet publication criteria. A unique, consistent, permanent citation identifier (CID) number is assigned to each article at the time of the first publication. Utilization of CIDs allows articles to be fully citable as soon they are published online, and connects the same identifier to all online, print, and electronic versions of the publication. SPIE uses a six-digit CID article numbering system in which:

- The first four digits correspond to the SPIE volume number.

- The last two digits indicate publication order within the volume using a Base 36 numbering system employing both numerals and letters. These two-number sets start with $00,01,02,03,04,05$, $06,07,08,09,0 \mathrm{~A}, 0 \mathrm{~B} \ldots \mathrm{OZ}$, followed by 10-1Z, 20-2Z, etc.

The CID number appears on each page of the manuscript. The complete citation is used on the first page, and an abbreviated version on subsequent pages. Numbers in the index correspond to the last two digits of the six-digit CID number. 


\section{Contents}

ix Conference Committee

xi Symposium Committee

\section{SESSION 1 HOLOGRAPHY AND INFORMATION OPTICS}

683702 Angular division multiplexing in pulsed digital holography for measurements of high resolutions (Invited Paper) [6837-76]

H. Zhai, X. Wang, C. Yuan, G. Mu, Nankai Univ. (China)

683703 Known plain text attack on the double phase encoding and its implementation with parallel hardware [6837-09]

H. Wei, X. Peng, Tianjin Univ. (China) and Shenzhen Univ. (China); H. Liu, S. Feng, Shanghai Institute of Microsystem and Information Technology (China); B. Z. Gao, Clemson Univ. (USA)

683704 Digital image measurement of specimen deformation based on CCD cameras and Image J software: an application to human pelvic biomechanics [6837-73]

Y. Jia, L. Cheng, G. YU, Y. Lou, Y. YU, B. Chen, Z. Ding, Tongji Univ. (China)

683705 1D Fourier transform in optical information processing [6837-75]

S. Jutamulia, Univ. of Northern California (USA); F. Song, China Daheng Corp. (China);

Y. Zhang, Central Univ. for Nationalities (China)

\section{SESSION 2 PATTERN RECOGNITION AND CORRELATORS}

683707 Rotation-invariant color pattern recognition based on the joint fractional Fourier transform correlator [6837-17]

Y. Zhang, W. Jin, Zhejiang Normal Univ. (China)

683708 Application of JTC in recognition and real-time tracking of moving targets [6837-46]

Y. Chen, H. Miao, W. Wang, Q. Zhu, Changchun Univ. of Science and Technology (China)

683709 Zone-processing joint extended fractional Fourier transform correlator [6837-37]

W. Jin, Zhejiang Normal Univ. (China); C. Yan, Zhejiang Lishui Vocational and Technical

College (China); Y. Zhang, Zhejiang Normal Univ. (China)

\section{SESSION 3 PHOTONIC AND OPTICAL COMPUTING}

6837 OB Application of optical tweezers using DOE and SLM to control of beads with informationDNA for photonic DNA computing (Invited Paper) [6837-72]

M. J. Zheng, Y. Ogura, J. Tanida, Osaka Univ. (Japan)

6837 OC A novel optical digital processor based on digital micromirror device [6837-18] H. Jia, J. Zhang, J. Yang, X. Li, W. Hu, National Univ. of Defense Technology (China) 
6837 OD Analysis on the Gaussian approximation of LPo1 mode [6837-64]

L. Li, F. Guo, R. Gao, Y. Peng, X. Tang, Fujian Normal Univ. (China)

$6837 \mathrm{OE}$ A novel scheme for simultaneously realizing optical millimeter-wave generation and remote photonic down-conversion in RoF system [6837-57]

H. Wen, L. Chen, S. Wen, Hunan Univ. (China)

\section{SESSION 5 WAVE AND PHYSICAL OPTICS}

6837 OF Three-dimensional beaming of surface plasmon polaritons generated by subwavelength metallic hole (Invited Paper) [6837-70]

H. Kim, J. Park, B. Lee, Inter-University Semiconductor Research Ctr. (South Korea) and Seoul National Univ. (South Korea)

6837 OG The position shifting of frequency spectrum of Fourier transform in the application of aspheric surface testing [6837-66]

J. Weng, Y. Yang, D. Liu, Y. Shen, Y. Zhuo, Zhejiang Univ. (China)

$6837 \mathrm{OH} \quad$ Optical sampling using a PPLN waveguide for optical performance monitoring [6837-55] M. Liu, A. Yang, Y. Sun, Beijing Institute of Technology (China)

6837 OI The application of underwater optics and its development [6837-39]

P. LV, Xi'an Institute of Optics and Precision Mechanics (China) and Graduate School of Chinese Academic of Sciences (China); J. He, R. Zhou, Xi'an Institute of Optics and Precision Mechanics (China); H. Liu, Xi'an Institute of Optics and Precision Mechanics (China) and Graduate School of Chinese Academy of Sciences (China)

\section{SESSION 6 NOVEL DEVICES AND TECHNIQUES}

6837 0J Duobinary RZ and dark RZ signals generation using only one differential Mach-Zehnder modulator [6837-21]

J. He, L. Chen, L. Liu, Y. Shao, S. Wen, Hunan Univ. (China)

6837 OK Transmission performance of optical millimeter wave generated by one modulator [6837-19]

C. Huang, L. Chen, S. Wen, Hunan Univ. (China)

$6837 \mathrm{OL}$ Theoretic analysis of pulse shaping by using nonlinear optical loop mirror based on crystal fiber [6837-26]

S. Li, A. Yang, Y. Sun, Beijing Institute of Technology (China)

\section{SESSION 7 OPTICAL COMMUNICATIONS}

6837 OM The application of the diversity in mobile free-space optical communication [6837-25]

Y. Li, R. Zhang, Shanghai Univ. (China) 
6837 ON Encoding and transmission of orthogonally optical label switching using DQPSK payload and MD-RZ label [6837-29]

Y. Shao, S. Wen, L. Chen, Y. Xiao, Hunan Univ. (China)

\section{POSTER SESSION}

$6837 \mathrm{OQ} \quad$ Novel method in solving non-polarizing condition in frustrated total internal reflection layers [6837-02]

J. Shi, Z. Wang, Harbin Engineering Univ. (China)

6837 OR Study on the quality control of online detection [6837-03]

X. Zhang, B. Zhang, X. Li, Tianjin Univ. of Technology (China)

6837 OS Novel sub-terahertz wave modulator based on photonic crystals [6837-04]

J. Li, J. Li, China Jiliang Univ. (China)

6837 OT Study of Fourier transform spectrometer based on Michelson interferometer wave-meter [6837-05]

Y. Peng, Beijing Univ. of Technology (China); L. Wang, Tianjin Univ. of Technology and Education (China); L. Lin, Beijing Institute of Technology (China)

6837 OU The multiphoton ultraviolet and visible upconversion luminescence of ZBLAN material [6837-07]

X. Chen, Beijing Normal Univ. (China); Z. Song, Peking Univ. (China); Y. Wang, J. Xiong,

G. Yang, S. Li, J. Zhou, F. Peng, G. Zhou, Beijing Normal Univ. (China)

6837 OV Larger depth of field for optical imaging methods [6837-11]

J. J. Wang, S. G. Sang, Z. Wang, X. T. Mo, W. Y. Liu, Tianjin Univ. (China)

$6837 \mathrm{OW}$ Characterization of the dispersion of chirped fiber Bragg grating through Fourier transform spectrometry method [6837-13]

Q. Chen, Beijing Univ. of Posts and Telecommunications (China) and Beijing Institute of Machinery (China); N. Lu, Beijing Univ. of Posts and Telecommunications (China); F. Jiang, Beijing Institute of Machinery (China)

6837 OX Improved LSB matching steganography with histogram characters reserved [6837-14] Z. Chen, W. Liu, Tianjin Univ. (China)

6837 OY Performance analysis of successive interference cancellation scheme for optical CDMA using modified prime sequence codes [6837-15]

T. Eltaif, Univ. Kebangsaan Malaysia (Malaysia); H. M. H. Shalaby, Alexandria Univ. (Egypt); S. Shaari, Univ. Kebangsaan Malaysia (Malaysia); M. M. N. Hamarsheh, Multimedia Univ. (Malaysia)

$6837 \mathrm{OZ}$ Thermoelastic mechanical process analysis of the laser-generated Lamb wave in thin fiber reinforced composite plate by numerical simulation [6837-16]

J. Wang, Nanjing Univ. of Science and Technology (China) and Jiangsu Univ. (China);

B. Xu, Jiangsu Univ. (China); Z. Shen, X. Ni, Nanjing Univ. of Science and Technology

(China); G. Wang, Nanjing Univ. of Science and Technology (China) and Jiangsu Univ.

(China); J. Lu, Nanjing Univ. of Science and Technology (China) 
683710 Extraction of guided waves by diffraction of 2D photonic crystals fabricated on the surface of waveguides [6837-22]

X. Chen, X. Zhang, S. Liu, X. Ren, Xiamen Univ. (China)

683711 Field depth extension of 2D barcode scanner based on wavefront coding and projection algorithm [6837-24]

T. Zhao, Z. Ye, W. Zhang, W. Huang, F. Yu, Zhejiang Univ. (China)

683712 Performance analysis on a new binary amplitude-based phase-only-encoded barcode [6837-27]

X. Wu, Dalian Maritime Univ. (China) and Dalian Univ. of Technology (China); J. Hu, K. Wu, Y. Lin, Dalian Univ. of Technology (China)

683713 Universal description of the optical coherence [6837-28]

Y. Huang, Y. Qiu, Z. Huang, Fujian Normal Univ. (China)

683714 All-optical wavelength converter based on self-phase modulation in highly nonlinear photonic crystal fiber [6837-30]

H. Yan, Y. Huang, Z. Weng, Y. Wang, R. Ye, Z. WU, J. Wan, Xiamen Univ. (China)

$683715 \quad 1.5-\mu \mathrm{m}$ band tunable wavelength conversion based on fan-out grating in QPM-LN [6837-32]

Y. Wang, Y. Huang, Z. Weng, H. Yan, R. Ye, J. Wan, Xiamen Univ. (China)

683716 Study on the spectral combination characteristic of grating [6837-36]

L. Wan, M. Huang, X. Huang, W. Zhang, Q. Yang, Guangxi Univ. (China)

683717 Influence of temperature on holographic gratings fabricated in photopolymer [6837-40] D. Feng, Shandong Univ. (China)

683718 An improved optic-electronic hybrid encoding technique for certificate validation [6837-41]

K. Wu, J. Hu, Dalian Univ. of Technology (China); X. Wu, Dalian Univ. of Technology (China) and Dalian Maritime Univ. (China); Y. Lin, Dalian Univ. of Technology (China)

683719 Detecting of Brillouin shift and sound speed in water with the method of ICCD image by time oriented sequential control [6837-42]

X. He, S. Li, Nanchang Hangkong Univ. (China); D. Liu, Beijing Normal Univ. (China)

6837 IA MMI power splitters based on the annealed proton exchange (APE) technology [6837-48] J. Cui, W. Chang, L. Feng, F. Cui, Y. Sun, Beijing Institute of Technology (China)

6837 1B A new calibration approach of rotor axes for 3D measurement system [6837-49] Q. Wu, J. Li, Shenzhen Univ. (China); X. Su, Sichuan Univ. (China); B. Hui, Shenzhen Univ. (China)

6837 1C Performance of optical DPSK and DQPSK in 40G bit/s transmission systems [6837-51]

J. Gao, J. Cui, L. Feng, F. Cui, Y. Sun, Beijing Institute of Technology (China) 
6837 1D Feature extraction on detecting target in clutter background with wavelet transform [6837-52]

H. Dong, C. Li, S. Chu, W. Wang, Changchun Univ. of Science and Technology (China)

6837 1E Enhancement technology of the joint transform power spectrum [6837-53]

C. Li, F. Chen, S. Chu, J. Zhao, W. Wang, Changchun Univ. of Science and Technology (China)

$6837 \mathrm{IF}$ Application of joint transform correlator in detection of infrared target [6837-54]

F. Chen, C. Li, D. Liu, W. Wang, Changchun Univ. of Science and Technology (China)

$68371 \mathrm{G}$ Self-reference hologram [6837-58]

L. Ma, Xidian Univ. (China); Y. Wang, Shaanxi Normal Univ. (China)

$68371 \mathrm{H} \quad$ Tracking technology of moving target with optical correlator [6837-60]

H. Miao, Y. Chen, F. Chen, W. Wang, Changchun Univ. of Science and Technology (China)

$683711 \quad$ Electromagnetic transmission of T-shape periodic metallic grating [6837-65]

Y. Wang, Harbin Institute of Technology (China); Y. Zhang, Capital Normal Univ. (China)

6837 1J New photonic bandgap of single negative materials [6837-68]

Y. Zeng, Northwestern Polytechnical Univ. (China); Q. Chen, Xi'an Institute of Optics and Precision Mechanics (China); J. Xu, Northwestern Polytechnical Univ. (China)

$68371 \mathrm{~K}$ Measurements of the hexagonal super-lattice pattern in a dielectric barrier discharge [6837-69]

W. Xie, L. Dong, H. Zhao, W. Liu, H. Wang, Hebei Univ. (China)

$6837 \mathrm{lL} \quad$ Modified deflection routing algorithm in optical burst switched networks [6837-71] J. Wang, L. Wu, Y. Song, Xiamen Univ. (China)

$68371 \mathrm{M}$ Implementation of OFDM multimode fiber communication system in the Simulink environment [6837-01]

W. Xie, G. Hu, Q. Deng, Jilin Univ. (China)

6837 iN Analysis of improved Lyot depolarization of residual polarization degree [6837-50] M. Wang, Z. Zhung, Fujian Normal Univ. (China); N. Wang, M. Huang, Foctek Optoelectronics Co., Ltd. (China)

Author Index 
Downloaded From: https://www.spiedigitallibrary.org/conference-proceedings-of-spie on 26 Apr 2023

Terms of Use: https://www.spiedigitallibrary.org/terms-of-use 


\title{
Conference Committee
}

\author{
Conference Chairs
}

Guoguang Mu, Nankai University (China)

Feijun Song, China Daheng Corporation (China)

Francis T. S. Yu, The Pennsylvania State University (USA)

Suganda Jutamulia, University of Northern California (USA)

Program Committee

Ken Y. Hsu, National Chiao Tung University (Taiwan, China)

Kazuyoshi Itoh, Osaka University (Japan)

Soo-Gil Kim, Hoseo University (South Korea)

Byoungho Lee, Seoul National University of Technology (South Korea)

Sar Sardy, University of Indonesia (Indonesia)

Kehar Singh, Indian Institute of Technology Delhi (India)

Yunan Sun, Beijing Institute of Technology (China)

Shiquan Tao, Beijing University of Technology (China)

Jun Uozumi, Hokkai-Gakuen University (Japan)

Joewono Widjaja, Suranaree University of Technology (Thailand)

Jinghui Xie, Beijing Institute of Technology (China)

Pochi Yeh, University of California, Santa Barbara (USA)

Shizhuo S. Yin, The Pennsylvania State University (USA)

Session Chairs

Holography and Information Optics

Feijun Song, China Daheng Corporation (China)

Pattern Recognition and Correlators

Suganda Jutamulia, University of Northern California (USA)

Photonic and Optical Computing

Feijun Song, China Daheng Corporation (China)

Wave and Physical Optics

Suganda Jutamulia, University of Northern California (USA)

Novel Devices and Techniques

Shiquan Tao, Beijing University of Technology (China)

Optical Communications

Shiquan Tao, Beijing University of Technology (China) 
Downloaded From: https://www.spiedigitallibrary.org/conference-proceedings-of-spie on 26 Apr 2023

Terms of Use: https://www.spiedigitallibrary.org/terms-of-use 


\title{
Symposium Committees
}

\author{
General Chairs \\ Brian Culshaw, University of Strathclyde (United Kingdom) \\ Bingkun Zhou, Tsinghua University (China) and COS-Chinese Optical \\ Society (China) \\ General Cochairs
}

Arthur Chiou, National Yang-Ming University (Taiwan, China)

Mitsuo Takeda, University of Electro-Communications (Japan)

Chungli Bai, Chinese Academy of Sciences (China)

Seung-Han Park, Yonsei University (South Korea)

Zhizhan Xu, Shanghai Institute of Optics and Fine Mechanics

(China)

Jianlin Cao, China Ministry of Science and Technology (China)

Junhao Chu, Shanghai Institute of Technical Physics (China)

Jingming Kuang, Beijing Institute of Technology (China)

Xiaomin Ren, Beijing University of Posts and Telecommunications (China)

Dingbo Kuang, Shanghai Institute of Technical Physics (China)

Guozheng Yang, Institute of Physics (China)

Honorary Chairs

Daheng Wang, Chinese Academy of Sciences (China)

Guoguang Mu, Nankai University (China)

Technical Program Chair

Songlin Zhuang, Shanghai University of Science and Technology (China)

Technical Program Cochairs

Xun Hou, Xian Institute of Optics and Precision Mechanics (China)

Qian Mao, Wuhan Research Institute of Posts and Telecommunications (China)

Xu Liu, Zhejiang University (China)

Local Organizing Committee Chair

Shusen Xie, Fujian Normal University (China)

Local Organizing Committee Cochairs

Guoqiang Ni, Beijing Institute of Technology (China)

Qihuang Gong, Peking University (China)

Ying Gu, PLA General Hospital (China)

Huilin Jiang, Changchun University of Science and Technology (China) 
General Secretary

Guoqiang Ni, Beijing Institute of Technology (China)

Administrative Vice General Secretary

Boyu Ding, Beijing Institute of Technology (China)

Vice General Secretaries

Hanyi Zhang, Tsinghua University (China)

Ya Cheng, Shanghai Institute of Optics and Fine Mechanics (China)

Zhongwei Fan, Academy of Opto-electronics (China)

Jianxin Chen, Fujian Normal University (China)

Lan Wu, Zhejiang University (China)

Shaowen Wang, COS-Chinese Optical Society (China)

Yuejin Zhao, Beijing Institute of Technology (China)

Chongxiu Yu, Beijing University of Posts and Telecommunication (China)

Jun Ruan, China Solid State Lighting Research and Industry Alliance

(China)

Local Organizing Committee Members

Kangnan Qi, Beijing Optical Society (China)

Chunqing Gao, Beijing Institute of Technology (China)

Tiegen Liu, Tianjin University (China)

Lanxing Shao, Shanghai Optical Society (China)

Zaixuan Zhang, Chinese Jiliang University (China)

Hongda Chen, Institute of Semiconductors (China)

Baosheng Liu, Beijing Optical Society (China)

Xin Wang, Hubei Optical Society (China)

Lin Zhai, COS-Chinese Optical Society (China)

Zhiqiang Zhu, East China Normal University (China)

Lei Xu, Fudan University (China)

Hezhou Wang, Zhongshan University (China)

Zhiming Yi, Ofstar Tech Company, Ltd., Shenzhen (China) 